\title{
Pentecostals' reading of the Old Testament
}

M Nel

(North-West University)

\section{ABSTRACT}

Pentecostals' reading of the Old Testament

The question of a valid and viable Pentecostal hermeneutic is discussed leading to the preliminary conclusion that such a hermeneutic would consist of the following elements: the experience of the immanence of God, within the charismatic community, through the work of the Spirit. The hermeneutic leads to a reading of Old (and New) Testament texts, especially narrative texts, as replicable for modern-day believers, because Pentecostals view the Bible as consisting primarily of testimonies of God's involvement and intervention in ancient believers' lives with the aim to duplicate those acts in modern believers' lives. The narratives of Pentecostals' preaching and testimony are based upon Biblical tales but they are also accompanied by the same signs and wonders the Bible testifies to. This causes Pentecostals' success in missions as non-literary societies are not interested in creeds but in oral narratives demonstrated in practice. Signs and wonders, healings and revelations, prophetic words and resurrections demonstrate the immanence of God as described in the Bible in a dramatic way to modern people.

\section{INTRODUCTION}

Do Pentecostals have a distinctive hermeneutic? What are those distinctives distinguishing such a hermeneutic from others? And how do these distinctives determine Pentecostals' reading of the Bible? These are the questions answered in this article, with emphasis on the consequences of such a hermeneutic for the reading of Old Testament texts. These questions have generated much discussion amongst Pentecostals in the last years (Thomas 1994:41).

That Pentecostals have a distinctive, consistent and viable hermeneutics or approach to the Scriptures is not agreed upon by all participants in the debate (Thomas 1994:41; cf. Clark, Lederle et al 1989:25-28 for a discussion of the viewpoints of W Hollenweger, R 
$\mathrm{N}$ Johnston, Gordon Fee who do not agree) ${ }^{1}$. Here it is argued that a distinctive hermeneutic is possible and necessary due to the difference between a Pentecostal or charismatic community where prophecy, speaking in tongues and interpretation of the tongues, healings and other miracles happen and the Bible is read from this experiential perspective, and other, non-charismatic communities where the Bible is read and interpreted "theologically" without this specific experiential perspective ${ }^{2}$. Thus the difference is in my opinion more fundamental than between, for instance, the Reformed and Roman Catholic, or sacramental, high church and Methodist type traditions.

There are problems in defining a Pentecostal hermeneutic due to the doctrinally and structurally heterogeneous nature of classical Pentecostalism. What unifies the many denominations and independent groups forming classical Pentecostalism is common experience and history rather than a common confession. Actually, confessions play a rather insignificant role amongst Pentecostals for whom the charismatic experience of the guidance of the Spirit is imperative. The movement also does not have a founding or guiding figure like John Calvin, Martin Luther or John Wesley, although quite a few pioneering figures in the movement's history are revered. There is no Pentecostal tradition but rather a Pentecostal ethos that establishes the practice and values found commonly in the

1 A selection of Pentecostal scholars who agree that a distinctive Pentecostal hermeneutic exists includes Menzies (1985); Spittler (1985); Autry (1993); Stronstadt (1993); Menzies (1994); Baker (1995); McQueen (1995); Ellington (1996); Penney (1997). An extensive bibliography is available in Thomas (1994:43; footnote 4). Some Pentecostals deny the need for a distinctive Pentecostal hermeneutic and prefer to follow current evangelical models (cf. Clark 1997a:53-90) while others are disappointed with the results of rationalism and want to emphasize the role of the Spirit and community in hermeneutic (Thomas 1994:41). “...the textuality of the evangelical community precludes fundamental aspects of Pentecostal experience and as such charismatic communities are often marginalized by mainstream evangelicalism... because conservative evangelicalism is shaped by a textualist theology, there is a fundamental tension in Pentecostal theology's attempt to work within evangelical frameworks" (Smith 1997:70).

2 Pinnock (2004:6), writing about a new interest in evangelical theology in the Spirit, asks what would happen if we gave priority to the Spirit, moving from the Spirit through the Son to the Father, and comes to the conclusion that there would be a difference of emphasis on every doctrine. 
movement (Clark 1997a:4). Although theological scholarship is found amongst Pentecostals, scholarly writings do not play a vital role in the lives of its practitioners, including pastors and other preachers. Many cases of anti-intellectualism have been described within the movement, especially in earlier years, in favor of a bias for the exclusive study of the Bible (Spittler 1985:56-58).

What is probably agreed upon by most Pentecostals is that their hermeneutic is informed by a pneumatic epistemology leading to the awareness that the Bible is the product of an experience with the Spirit which Biblical writers described in phenomenological language. To understand this phenomenological language is more than an exercise in semantics or descriptive linguistics but rather in developing a lifestyle that accommodates the same experiences with the Spirit (Ervin 1985:33).

The implication is that Pentecostals tend to use the Bible to propagate a spiritual experience in continuity with what they consider Biblical figures experienced. Their concern is with practice rather than with belief and doctrine. "...the role of Scripture is to serve as confirmation and guideline to the dynamic of the Spirit..." (Clark, Lederle et al 1989:101). The practice of Pentecostals is based on their interpretation of the Spirit baptism and its accompanying release of power in the lives of the baptized and their interpretation of the Bible is based on this perception and experience. From the experience follows theology. "First comes the act of God, then follows the attempt to understand it" (Bond 1989:135).

Thomas (1994:42-43) writes that just as Pentecostals have been able to help the church rediscover a number of Biblical truths with regard to pneumatology, "so they may also have gifts to give when it comes to the interpretive process itself" ${ }^{3}$.

\section{PROPRIA OF PENTECOSTALS' SELF-UNDERSTAN- DING}

Several attempts have been made to outline the propria of the Pentecostal movement's theology and practice. The most popular is probably the attempt to describe the movement in terms of one of its earliest confessions, Jesus Christ as Savior, Healer, Baptizer in the

3 Thomas (1994) uses the process followed in the early church to reach the decision about whether Gentiles should form part of the Christian church to inform his hermeneutic (See Acts 15:1-29). 
Spirit, and Coming King. This is based on the so-called Foursquare Gospel of Aimee Semple McPherson, controversial founder of the International Church of the Foursquare Gospel, whose message is:

Jesus saves us according to John 3:16. He baptizes us with the Holy Spirit according to Acts 2:4. He heals our bodies according to James 5:14-15. And Jesus is coming again to receive us unto Himself according to 1 Thessalonians 4:16-17 (Dayton 1987:21).

In some branches of Pentecostalism sanctification is also emphasized, as a residue of the holiness movement, one of the originating factors of the Pentecostal movement (Dayton 1987:20) ${ }^{4}$.

According to this formulation the Pentecostal movement is actually more christological that pneumatological, with Christ the acting agent in the Church and whose imminent return gives Pentecostal missions its urgency and believers the impetus to obey and follow their Master (discipleship movement) ${ }^{5}$.

The expectation of Pentecostal believers is to experience Christ as their Savior, Baptizer in the Spirit, Healer and, through the working of his Spirit, also as Sanctifier. Thus the widespread notion amongst Pentecostals that this history of God with his people, starting in the Bible, is continued and accompanied by the same phenomena until the present day, and the narratives in the Bible of people's encounters with God are seen as normative for present-day believers. These narratives are understood literally, and taken to be repeatable and expected, and Biblical characters' experiences are to be emulated. In this way Pentecostalism shares the primitivism of movements such as Montanism and the Anabaptists that the earliest Church was the only to be unpolluted by later events determined

$4 \quad$ The influence of the different movements that preceded the Pentecostal movement and eventually contributed to it has been described, in the Holiness and Methodist, healing and deliverance movements.

5 "For the Pentecostal, Christ is not just an object of faith: someone in whom I believe, to whom I am attached by faith. The risen Lord is the subject of the Pentecostal's experience of God. By the agency of his Spirit, it is Christ who saves, who heals, who baptizes in the Spirit, will come again for his people" (Clark, Lederle et al 1989:47). 
largely by the cooperation between church (pope) and (the Roman) state (Bruner 1970:26; Poirier \& Lewis 2006:4).

Others understand Pentecostalism in terms of its spirituality with its component parts of power and holiness, both the exclusive work of the Spirit in the believer's life (Land 1993:23; cf. also Cronjé 1981; Hattingh 1984; 1989). Some follow in this tradition by emphasizing obedience and morality (McQueen 1995; Moore 1995), with the Pentecostal as a stranger among and to the values and ways of the world $)^{7}$.

Anderson (1991:26-29, 100-116; 1992) investigates African understanding of the power of the Spirit or Moya, and describes its distinctives in terms of its holism; understanding of prophets and prophecy against the contexts of the Old and New Testaments; the role of anointed leadership; the guidance of the Spirit; healing and miracles; and body-movement during worship.

Johns (1995:88-102) discusses the characteristics of a Pentecostal world-view as God-centred; trans-rational; and apocalyptic $^{8}$. Scripture plays a major role with the aim to facilitate an encounter with God leading to a new understanding of the world based upon belief in God's involvement in and control over the world. Pentecostals also have a strong sense of the need to live in separation from the world in surrender to God's will. The essence and core of its knowledge is to know God (in the sense of the Hebrew yada') which consists of an encounter between man and God; its a priori metaphor is narrative or revelation; its foundation of understanding is tradition; and its primary approach to truth is through community and rituals (Johns 1995:95).

6 The name of the largest classical Pentecostal denomination in South Africa, the Apostolic Faith Mission, informs on the movement's preoccupation with its being a continuation of what happened in the apostolic period in the earliest Church, with emphasis on faith as the means to experience an encounter with God and the resulting call to live as a missional church.

7 Clark (2006) discusses the separateness of Christians as a distinctive of early Christians, with twentieth century Pentecostals as a sequence to it.

8 Dayton (1987:143ff.) notes the essential role played by eschatological expectation amongst Pentecostals from its beginnings, and Faupel (1996:28-30) shows how this expectation determined the names adopted in the movement for the different denominations as an essential part of Pentecostal ethos. 
To summarize, the propria of Pentecostals' self-understanding are: a radical, apocalyptic, disciple-centred, missional, Jesus-centred and encounter-expecting movement without any national, cultural, political or cultural coherence (Goff 1988:163; Kraus 1979:173-175 describes Anabaptism in nearly the same terms).

Pentecostals' emphasis that Biblical narrative is repeated in the present day has led to the observation that they have sided with fundamentalism against higher criticism (thus Hollenweger 1977:291-307, against Barr's 1977:208 view that Pentecostalism has something more positive to offer $)^{9}$. This is not necessarily true as Pentecostals view the Bible not as a book about human history and certain religious phenomena but as a testimony of the way God and human beings relate to each other, through the ages up to the present day $^{10}$. For this reason testimonies or witnesses play an essential role in Pentecostal worship services with people telling about their encounter with God, and in many cases in simulation of and in terms that reflect Biblical encounters. The Biblical history is expected to be repeated and the aim in services is not to teach doctrine or confessions but to experience and act (Clark 1997a:40). This does not imply that all Pentecostals have a naïve, biblicistic understanding of the Bible, even though it must be admitted that it occurs amongst certain groups (cf. Horn 1989 for a discussion of such groups).

\section{A PENTECOSTAL HERMENEUTIC}

The most important elements of a Pentecostal hermeneutic seem to be:

\subsection{Emphasis on the immanence of God}

The Bible is read by Pentecostals in terms of their perception of God among them. "...God is as much a causative agent today as he is pictured in the biblical writing” (McLean 1984:38). The Bible is not viewed as a source-book for doctrine but rather as a blueprint for living. Sometimes it has happened in Pentecostal groupings that the Bible was interpreted as a system of laws regulating every aspect of

9 "Fundamentalism" is defined as "a belief in the verbal inspiration and the literary inerrancy of the Bible, and the affirmation of the confessions of the Reformation'.

10 The reality of the discontinuation between the cultural, political, socioeconomical and religious worlds of the Bible and the modern believer cannot be denied, and Pentecostal circles probably do not make enough of this. 
life as an extreme form of obedience to the Bible but for the most part Pentecostals read the Bible rather with the expectation that what happened to people in the Bible will be duplicated in their lives. From this comes the emphasis on Biblical narrative as a description of what should be expected by modern day believers but also the desire of Pentecostal people to live in "the world of the Bible", or with a Biblical world-view determined by faith in God's immanence in and dominion over the daily lives of believers and this world. "To live in the world of the Bible" refers to Pentecostals' desire to experience the same kinds of encounters with God that characters in the Bible experienced; to apply "Biblical truths" to daily living; to demonstrate the power of the God of the Bible to modern, secular man; and to realize the gifts and fruit of the Spirit through their lives. Although this is sometimes done in a biblicistic way without consideration of historical discontinuities between the Biblical and modern world, in many cases it leads to radical discipleship of and witness to Jesus Christ.

Pentecostals understand that the great events in Christ's life is not repeatable but expect that their lives will follow the pattern of first century believers as well as believers in Old Testament times. No serious discontinuation exists in their opinion between the way God revealed and is revealing Himself.

The Bible is read pneumatologically, that is, in terms of the modern believer's experience of the fullness of the power of God. The experience of being baptized with the Spirit informs the way the Bible is read (Dayton 1985:134; McQueen 1995:11). “...people must have had an encounter - or rather, should have an ongoing encounter - with God before they can really say anything about him, i.e., before they can do theology” (Hattingh 1989:154).

Pentecostal people also find a world-view in the Bible that they appropriate for themselves ${ }^{11}$. This world-view does not refer to the "scientific", especially cosmological, view that Biblical writers used to describe the world but rather to the philosophical, determined by questions such as “who am I?”, "why am I here?” and "where am I going?” The answers to these questions stand in direct contrast to

11 Most researchers would deny that a uniform world-view can be found amongst the books of the Bible but Pentecostals, reading the Bible holistically, witness to finding such a viewpoint. 
those provided by (post-)modern culture in Pentecostals' view, and they understand themselves in terms of their distinction from and rejection of this culture and in separation from it. They see themselves as a continuation of the revelation of God in the Bible and find their lives' meaning in being part of "God's plan for this world”. By understanding the Bible in terms of the immanence of God through his Spirit, they criticize the consensus ethic of their day. The Bible is interpreted as a direct challenge to society's deepest held and most cherished assumptions by providing alternative values.

Ervin (1985:33), in describing his "pneumatic hermeneutic", emphasizes that the self-understanding of Pentecostals is determined by direct continuation with the faith community that birthed the Bible. Cronjé (1981:38) writes that Spirit-filled Corinthians would follow Paul's arguments about the working of the Spirit in worship services due to their having had the same experience of the Spirit that he had, while modern day believers lacking this dimension have difficulty understanding these passages. In the words of McDonald (1976:66), "Either you know what I am talking about (by experience) or you do not. If you do not, you would not know if I told you". This is also the experience of many newcomers to the Pentecostal experience, that the Bible has become a new book for them (Ervin 1985:33).

Another researcher, McKay (1994:18), concludes that there are in his view at least two ways of studying the Bible: objectively and analytically, imparting little or nothing of the life and power of God; and engagingly, through the infilling of the Spirit. In this way Biblical prophecy is understood not in a literal, mechanistic view of inspiration as words dictated by God, but rather in terms of the modern assembly's experience of prophecy as inspired but filtered through a human channel with the (expected) result of a near approximation of what God wants to communicate (McKay 1994:29). Cronjé (1981:16-17) refers to Peter's sermon on the day of Pentecost where he quoted from the Old Testament but does not use it word for word and letter for letter, but gives a free interpretation of the written format to contain new ideas revealed to him because he was anointed with power and faith.

Thus the point of departure in reading the Bible is "what does God want to do for us?" and "where is He leading us?”, and not “what is the correct doctrine?” (Thomas 1994:50). 


\subsection{Role of biblical narratives}

Mention has already been made to Pentecostals' preference for biblical narratives supporting their expectation of the same encounters with God as in Biblical times. This led to the primary use of the Bible in preaching and missions rather than in catechetics or theological training (Clark 1997a:150). The Bible is to be implemented, demonstrated and realized rather than understood. The emphasis is on the practice, the experience of the modern believer, of the divine reality that the Bible witnesses to. The aim of Pentecostal preaching is to change lives, and situations and narratives in the Bible provide excellent material to demonstrate this change brought about by the working of the Spirit. The Bible is used to demonstrate and actually bring about the change that God intends for people through the Spirit's anointing on them. Participants in the worship service also expect that something dramatic would happen to them or at least to some of those attending the service. While Protestants emphasize orthodoxy, Pentecostals stress orthopraxy (Clark, Lederle et al 1989:64).

The goal in preaching is connected directly to listeners' lives, in explaining the text not in order that the listener will be changed by the text but by the direct encounter with the God to whom the text testifies. The sermon is in the last instance not concerned with the characters or the world of the text but God who in the lives of modern believers acts as Savior, Healer, Baptizer in the Spirit and Comforter. In many instances the outcome of the sermon exceeds the subjective effect of the text through the resulting moving of the Spirit in people's lives. In Hattingh's (1984:223) words, if only words happen in the worship service when the great deeds of God are proclaimed, the church's integrity is to be questioned.

Biblical tales are taken as "patterns" according to which God works, illustrations of people who are pleasing to God and people in need waiting upon God. They do not depict what happened in the encounter between the human and divine but rather the how of this encounter. They are repeatable and re-livable. The biblical narratives are testimonies of how people experienced God with the invitation to expect the same experience today (Ellington 1996:29). In its turn it leads to testimonies of modern people's encounters with the divine, a new oral and experiential tradition seen in the same light as biblical narratives. 
The authority of the Bible is seen to be vested in the working of the Spirit in and through the Bible in the lives of the modern members of the charismatic community (Ellington 1996:27). This implicates that instead of understanding the authority of the Bible as lying in uniform propositions and the resultant description of doctrine, authority is understood to include a respect for the text's literary genre and the diversity as well as the unity of Scripture (Thomas 1994:55) ${ }^{12}$. The text does not function in a static manner but dynamically, making necessary an intensive engagement with it in order to discover its truths in ways that go beyond the cognitive. The play starting in the Bible is still running and the biblical testimonies are carried on in modern testimonies of the encounter with God, and the Bible receives its authority from this experience of its relevance for modern people.

The question asked by Pentecostals is not, "Do we believe what the Israelites in the Old Testament and the believers in the New Testament believed?" but rather, "Do we experience what the Israelites in the Old Testament and the believers in the New Testament experienced?" This implies that the narratives describing the experiences of believers form an essential part of Pentecostals' use of the Bible.

\subsection{Role of charismatic community}

The debate about the discontinuance of the charismata beyond the apostolic age uses the premise that the church has a canon that is closed and it has no need for ongoing revelation. These revelations were only necessary until the canon was closed and in some instances to found the canon. Now it is only possible to claim that the Lord is speaking by quoting the Bible.

Although Pentecostals usually have a high regard for the Bible they expect to hear directly from God, through a sermon or their devotions. Sometimes this "word of God" is based on something written in the Bible but there are cases when it refers to a prophecy, interpretation of tongues, or some other kind of "revelation". If the

12 Clark (1997b:9-10) finds the Bible's authority in its conceptualization of a world-view, making it the final authority for lifestyle and values, formulation of dogma, the encounter between God and man, and Christian proclamation. 
canon is accepted as closed, how are these revelatory utterances to be interpreted? ${ }^{13}$

Pentecostals acknowledge that the contemporary revelation should in all cases be distinguished from Biblical revelation ${ }^{14}$. Prophetic utterances are to be subjected to testing against the Bible. The authority of prophecy is derived from its consistency with the Bible, and prophecy is limited to a specific time, people and situations ${ }^{15}$. The evaluation of prophetic utterance is the responsibility of the charismatic community, the people equipped by the Spirit to discern what is pleasing to the Lord (1 Cor 14:29).

Pentecostals claim that much of the Bible is the product of the charismatic community in Biblical times ${ }^{16}$, and the ongoing charismatic experience of modern believers is a logical extension of that history, where God is still acting and leading his people through his Word. The Bible testifies to the presence of God in a charismatic way in the ancient and modern charismatic community. The "charismatic community" is understood as the people brought together by the Spirit as a demonstration of the immanence of God ${ }^{17}$. It is the body of Christ established through the Spirit by means of gifts given to people (Hattingh 1984:42) and people given as gifts to the church $^{18}$.

13 Sometimes the distinction is made in Pentecostal circles between a logos as the Word of God to be found in the Bible, and a rhema as the Word for a specific situation as applied by the Spirit. This is not a Biblical distinction of the terms. Cf., e.g., Smith (1997:55).

14 In the Faith movement the words of the leader is given equal authority as the Bible, leading to many dangers.

15 Cp. also Bezuidenhout's (1980:336-338) and Cartledge’s (1994:114-120) evaluation of prophecy based on 1 Corinthians 12.

16 Cf. the remark of Smith (1997:50) that the Israelite community was a community not centered around scribes but prophets. And Christianity was not a religion of the Book, though it was certainly a religion of the Word.

17 Hattingh (1984:5) calls this community a pneumatological theocracy which is charismatic in nature, revelation and ministry.

18 Pinnock (2004:13) notes that the time is ripe for a Spirit ecclesiology by invoking the Spirit and the animation of his life, in unrestricted openness to the gifts and to being built up into a habitation of God by the Spirit, becoming a community which experiences the continuation of the anointing of Jesus. 
Modern prophetic utterances use mainly biblical semiotics to explain by association what is believed the Lord wants to bring to the attention of modern believers. And in many cases it is biblical characters and incidents, especially tales from the Old Testament that are used as illustrations in modern prophecy.

The community functions as the place where the Spirit acts. Here believers give testimonies of God's involvement and intervention, and the community assesses and accepts or rejects it. The community also considers the acts of God and the Scripture and offers accountability (Thomas 1994:55).

\subsection{Role of the Spirit}

Reformers have understood the "illumination of the Spirit" as essential in reading the Bible but Pentecostals' understanding of this notion goes far beyond it (Arrington 1988:382; Thomas 1994:49, 55). It goes beyond mere cognitive apprehension of Scripture and includes a pneumatic epistemology that takes place in a lived experience where believers "hear from the Lord" while reading the Bible and a preacher's sermon is based on the supposition that he/she "has heard from the Lord" ". What Pentecostals expect in reading the Bible is "'a touch of the power of God in Jesus', descriptive of the experience which Pentecostals consider essential, valid and adequate" (Clark, Lederle et al 1989:102; authors' emphasis). God's ongoing history with people is mediated by the Spirit. The believer's participation in this history is via a personal experience with the Spirit starting with the baptism in the Spirit. And through the Spirit the Biblical drama becomes the believer's own story, by means of a powerful life-changing encounter with the Spirit, with the believer enlisted into the cast, and given a role in the plot (Clark 1997a:164).

In the process of interpreting the Bible, Pentecostals read the content but also respond to fresh, new things the Spirit does (Cartledge 1996:121-125) ${ }^{20}$. What is necessary in reading the Bible

19 The preacher is also acting ex spiritu rather than ex officio (Clark, Lederle et al 1989:69).

20 Cartledge discusses the five statements concerning the Paraclete provided in the Gospel of John: He gives the ability to love and obey; He teaches and reminds of Christ; He testifies about Jesus; He convicts unbelievers; and He guides into all truth. 
is, in Arrington's (1994:104-105) words, submission of the mind, with its critical and analytical capabilities; genuine openness to the witness of the Spirit while reading the Bible; personal experience of faith as part of the interpretive process; and response to the transforming call of God's word (cf. also Menzies 1985:10-14). "No one but the Holy Spirit provides the bridge that enables the ancient author and modern interpreter to meet and to span the historical and cultural gulf between them. The heart of the biblical text remains ambiguous until it is illuminated by the Holy Spirit” (Arrington 1994:105) ${ }^{21}$.

Reading the Bible may not stop with an understanding of the words, concepts, and events. It must rather seek so arrive at the transcendent realities to which the language testifies. More than reason is needed to comprehend the message of the Bible; the light of the Spirit is also needed. And as one grows in the life of the Spirit, the capacity to understand and experience the realities described in the Bible also grows (Pinnock 2004:16-17). The Bible is a dead letter until God speaks through it.

\section{SOME IMPLICATIONS FOR THE READING OF THE OLD TESTAMENT}

Pentecostals identify with characters from the Old Testament and base their expectation of what God wants to do for them on the narratives of the Old Testament. This does not imply that the work of the Spirit in the Old and New Testament is equated. God's presence in Old Testament times was experienced sporadically and selectively, or as Horton (1934:14) expressed it, the operation of the Spirit in the Old Testament was like a radio-controlled airship in distinction to a piloted airship in the New Testament. This is accepted by Pentecostals, that the priesthood and prophethood were limited to specific individuals in the Old Testament while the New Testament describes every believer as a priest and prophet ${ }^{22}$. The temple and priest mediated between the deity and ordinary believers while the

21 A lack of effective description of the role of the Spirit and development of models for understanding it is a limitation in Pentecostal theology and is due to the problematical character of describing it.

22 The priesthood of believers rests on the assumption that the church consists of all the saved, with each one having an equal chance in the liturgy and only distinguished from others in gifts and ministry (Clark, Lederle et al 1989:71). 
baptism with the Spirit leads to each individual having direct, unmediated contact with God.

A Pentecostal approach to hermeneutics embedded within the charismatic community of believers leads to a credible use of the Old Testament ${ }^{23}$. In discussing Joel, McQueen $(1995: 15)$ is of the opinion that we should not only ask how to interpret the book of Joel but also how Joel interprets modern readers. Biblical hermeneutics is preliminary to and serves the work of God in our lives. We read the Bible in order to create room for the Spirit to change our lives. He ends his discussion of the book of Joel with the testimony, "The same God who called and enabled me to lament, also poured out the Spirit on me, as the book of Joel, the New Testament, and the Pentecostal community had promised”.

The question can be raised whether Pentecostals have developed the historical consciousness necessary to do justice to the Bible as a historically situated and determined document. Whether this is the case needs to be investigated in a scientific way, but what is true is that Pentecostals read the Bible well aware of the historicity of what happened two or three millennia ago while also expecting the same God to reveal his power and love to them. Abraham, Moses, David and Daniel are well-known figures that are emulated by modern Pentecostals.

Pentecostals do not have a uniform viewpoint about the infallibility and inerrancy of the Bible. These issues are not very relevant for them because they do not base their belief upon the Bible as such but rather see the Bible as testimonies of God's involvement in ancient believers' lives with the aim to replicate those acts of involvement in modern believers' lives.

Due to their interest in Biblical narratives Pentecostals use the Old Testament rather eclectically ${ }^{24}$. Although some parts of classical Pentecostalism have tended to become legalistic, the legal parts of the Torah have not received much attention and the same can be said of parts of the Wisdom literature like Qohelet and the Song of Songs.

23 For examples, cp. McQueen's (1995) study of Joel, Moore's (1995) discussion of Deuteronomy, as well as Wessels' (1997) explanation of Joel.

24 The same is true of their use of the New Testament. The same can also be said of most other theological groupings, that theological conditioning determines which parts of the Bible is studied and appreciated the most. 
Pentecostals read the narratives and prophecies as well as the small amount of apocalyptic passages and enjoy the Psalms.

Pentecostal missions have been spectacularly effective, partly due to the emphasis on orality and narrative ${ }^{25}$. The narrative of Pentecostals is based upon Biblical tales but also accompanied by signs and wonders ${ }^{26}$. Non-literary societies are not interested in intellectually satisfying creeds but in oral narratives demonstrated in practice. "In the Third World the demonstration of the healing power of Jesus Christ probably remains the single most crucial factor in the continuing spread of the Pentecostal movement" (Clark 1997a:156). Signs and wonders, healings and revelations, prophetic words and resurrections demonstrate the immanence of God in a dramatic way.

A good summary of this discussion is found in Thomas' (1994:46-47) reflection on Acts 15, where Peter uses Amos 9:11-12 in its LXX form, while other passages might have been more useful for his purposes of validating the Gentiles' partaking in salvation, like Isaiah 2:3; 42:6; Micah 4:2 and Zechariah 2:11. Thomas' conclusion is that Acts 15's use of the text emphasizes the role of the community under the leadership of the Spirit, as well as the role the Spirit plays in the interpretive process. The interpreters of the Old Testament text move from context to the Biblical text, and the Biblical text is assigned and functions with a great deal of authority in this hermeneutical approach (Thomas 1994:50). The early church based its interpretation of the Old Testament upon the community, the activity of the Spirit, and the Scripture.

\section{Consulted literature}

Anderson, A H 1991. Moya: The Holy Spirit in an African context. Pretoria: University of South Africa.

-, 1992. Bazalwane: African Pentecostals in South Africa. Pretoria: University of South Africa.

Arrington, F L 1988. Hermeneutics, Historical perspectives on Pentecostal and charismatic, in Burgess, S M \& McGee, G B (eds.). Dictionary of

25 Smith (1997:53) remarks that orality was also the primary or primordial way of being for the New Testament community.

26 The greatest factor contributing to large crowds attending John G Lake's services in Doornfontein in 1908 was the healing of the employee of a wellknown affluent lady leading to the employer also attending the services and getting healed (Burger 1987:167). 
Pentecostal and charismatic movements. Grand Rapids: Zondervan, 376389.

-, 1994. The use of the Bible by Pentecostals. Pneuma 16, 101-108.

Autry, A C 1993. Dimensions of hermeneutics in Pentecostal focus. Journal of Pentecostal Theology 3, 29-50.

Baker, R O 1995. Pentecostal Bible reading: Toward a model of reading for the formation of Christian affections. Journal of Pentecostal Theology 7, 34-48.

Barr, J 1977. Fundamentalism. London: SCM.

Bezuidenhout, M E J 1980. Pauliniese kriteria ten opsigte van die beoefening van die charismata. 'n Eksegetiese studie van 1 Kor 12-14. DD dissertation, University of Pretoria.

Bond, J 1989. What is distinctive about Pentecostal theology, in Clark, M S, Lederle, H I, et al 1989. What is distinctive about Pentecostal theology? Pretoria: University of Pretoria, 133-142.

Bruner, F D 1970. A theology of the Holy Spirit. Grand Rapids: Eerdmans.

Burger, I 1987. Geloofsgeskiedenis van die Apostoliese Geloof Sending van Suid-Afrika 1908-1958. Braamfontein: Evangelie.

Cartledge, M J 1994. Charismatic prophecy: A definition and description. Journal of Pentecostal Theology 5, 79-120.

-, 1996. Empirical theology. Towards an evangelical-charismatic hermeneutic. Journal of Pentecostal Theology 9, 115-126.

Clark, D V 2006. The separateness of Christians in their interaction with the public life of imperial Romans, AD 50-313. M A dissertation, University of Johannesburg.

Clark, M S, Lederle, H I, et al 1989. What is distinctive about Pentecostal theology? Pretoria: University of South Africa.

Clark, M S 1997a. An investigation into the nature of a viable Pentecostal hermeneutic. DTh dissertation, University of South Africa.

-, 1997b. The nature and authority of Scripture, in Gräbe, P J \& Hattingh, W J. The reality of the Holy Spirit in the church. In honour of F $\mathrm{P}$ Möller. Pretoria: J L van Schaik, 1-13.

Cronjé, F H J 1981. Waarom Pinkster. Johannesburg: Evangelie Uitgewers.

Dayton, D W 1985. The use of Scripture in the Wesleyan tradition, in Johnston, R K (ed.). The use of the Bible in theology: Evangelical options. Atlanta: John Knox, 121-136.

-, 1987. Theological roots of Pentecostalism. Metuchen, NJ: Scarecrow.

Ellington, S A 1996. Pentecostalism and the authority of Scripture. Journal of Pentecostal Theology 9, 16-38.

Ervin, H M 1985. Hermeneutics: A Pentecostal option, in Elbert, P (ed). Essays on Apostolic themes: Studies in honour of Howard M Ervin. Peabody, MA: Hendrikson, 23-35. 
Faupel, D W 1996. The everlasting gospel: The significance of eschatology in the development of Pentecostal thought. Sheffield: Sheffield Academic Press.

Goff, J R 1988. Fields white unto harvest: Charles F Parham and the missionary origins of Pentecostalism. Fayetteville: University of Arkansas Press.

Hattingh, W J H 1984. Verkondiging en viering as terapeutiese momente in die pastorale versorging. D Th dissertation, University of South Africa.

Hattingh, W J H 1989. The proprium of Pentecostal theology, in Clark, M S, Lederle, H I, et al 1989. What is distinctive about Pentecostal theology? Pretoria: University of South Africa, 153-157.

Hollenweger, W 1977. The Pentecostals. Minneapolis: Augsburg.

Horn, J N 1989. From rags to riches. An analysis of the Faith movement and its relation to the classical Pentecostal movement. Pretoria: University of South Africa.

Horton, H 1934. The gifts of the Spirit. Michigan: Harold Horton.

Johns, J D 1995. Pentecostalism and the postmodern worldview. Journal of Pentecostal Theology 7, 73-96.

Kraus, C N (ed.) 1979. Evangelicalism and Anabaptism. Scottdale, PA: Herald.

Land, S J 1993. Pentecostal spirituality. A passion for the kingdom. Sheffield: Sheffield Academic Press.

MacDonald, W G 1976. Pentecostal theology: A classical viewpoint, in Spittler, R P. Perspectives on the New Pentecostalism. Grand Rapids: Baker, 58-74.

McKay, J 1994. When the veil is taken away. The impact of prophetic utterance on biblical interpretation. Journal of Pentecostal Theology 5, 17-40.

McLean, M D 1984. Toward a Pentecostal hermeneutic. Pneuma 6, 35-56.

McQueen, L 1995. Joel and the Spirit: The cry of a prophetic hermeneutic. Sheffield: Sheffield Academic Press.

Menzies, W W 1985. The methodology of Pentecostal theology: An essay on hermeneutics, in Elbert, P (ed). Essays on Apostolic themes: Studies in honour of Howard M Ervin. Peabody, MA: Hendrikson, 1-14.

Menzies, R P 1994. Jumping off the postmodern bandwagon. Pneuma 16, 115120.

Moore, R D 1995. Deuteronomy and the fire of God: A critical charismatic interpretation. Journal of Pentecostal Theology 7, 11-33.

Penney, J 1997. The testing of New Testament prophecy. Journal of Pentecostal Theology 10, 35-84.

Pinnock, C 2004. The recovery of the Holy Spirit in evangelical theology. Journal of Practical Theology 13.1, 3-18.

Poirier, J C \& Lewis, B S 2006. Pentecostal and postmodern hermeneutics: A critique of three concepts. Journal of Pentecostal Theology 15.1, 3-21. 
Smith, J K A 1997. The closing of the Book: Pentecostals, Evangelicals, and the sacred writings. Journal of Pentecostal Theology 11, 49-71.

Spittler, R P 1985. Scripture and the theological enterprise: View from a big canoe, in Johnston, R K (ed). The use of the Bible in theology: Evangelical options. Atlanta: John Knox, 56-77.

Stronstadt, R 1993. A review of Gordon D Fee, Gospel and Spirit: Issues in New Testament Hermeneutics. Pneuma 15, 215-222.

Thomas, J C 1994. Woman, Pentecostals and the Bible: An experiment in Pentecostal hermeneutics. Journal of Pentecostal Theology 5, 41-56.

Wessels, W J 1997. Spiritual renewal of a people: Joel 2:28-32, in Gräbe, P J \& Hattingh, W J. The reality of the Holy Spirit in the church. In honour of F P Möller. Pretoria: J L van Schaik, 53-63. 